\title{
KEGIATAN MEMBATIK PADA ANAK USIA 7-8 TAHUN DI SANGGAR SENI DAN BUDAYA
}

\author{
Lina Indra Kartika
}

\begin{abstract}
Batik painting is one of the art learning activities conducted in Sanggar Seni dan Budaya Jawa Jawi Java, Jakarta Selatanffor the children of 7-8 years. Introducing batik paitning for the early age children is something interesting to know because this activity is also a part of cultural heritage. This research which was conducted in 2008, aimed at desacribing how batik painting is organized in Sanggar Seni dan Budaya Jawa Jawi Java. The data were collected by using observation, interview, and document study techniques. As a descriptive research, the research findings ptovided clear description of batik painting as a learning activity and gave some comments and suggestions to improve.
\end{abstract}

Key words : batik painting, learning to paint, the characteristics of the children of 7-8 years.

\section{PENDAHULUAN}

Masa anak-anak merupakan masa pertumbuhan dan perkembangan yang sangat pesat. Masa tersebut juga sangat penting untuk mengenal lingkungan, termasuk hal-hal yang menjadi identitas bangsa. Batik merupakan salah satu indentitas Bangsa Indonesia, yang menjadi kebanggaan Bangsa Indonesia dan merupakan salah satu budaya yang perlu dilestarikan. Hal tersebut akan baik jika dimulai sejak anak-anak. Pengenalan seni membatik pada anak dianggap sesuai saat usia 6 tahun ke atas. Selain sudah dapat mengantisipasi resiko, pengetahuan terhadap warisan budaya dapat menjadi tambahan pengetahuan yang dapat menunjang pelajaran di sekolah. Kesabaran, ketekunan, dan kreativitas anak terasah dengan mempelajari teknik membatik.

Pada anak usia 7-8 tahun, keunikan dan potensi yang beragam pada setiap anak juga menjadi titik tolak dalam merancang kegiatan membatik yang efektif sesuai bagi perkembangan anak. Hal ini dikarenakan pada usia tersebut banyak aspek perkembangan dalam diri anak yang perlu dan harus dikembangkan secara optimal. Selain itu, anak usia 7-8 tahun juga berada pada masa transisi di mana daya kreasi, imajinasi, dan kreativitas dalam diri anak mulai berkembang. Anak usia 7-8 tahun memiliki karakteristik yang berbeda dengan karakteristik anak yang berada pada tahap perkembangan di atasnya. Anak pada usia ini telah memiliki kemampuan berpikir dan mulai memiliki kesadaran akan pilihan yang bagus dan tidak bagus, yang benar dan salah. Pada usia ini, mereka berkembang dan mata mereka terbuka lebar untuk mengetahui hal-hal mengenai unsur-unsur seni, yaitu garis, bentuk, warna, dan tekstur dalam teknik kegiatan membatik. Pada usia 7-8 tahun, perkembangan kemampuan motorik halus anak juga mencapai kondisi matang sehingga gerakan-gerakannya mulai dapat dikontrol dan diarahkan.

Membatik merupakan bagian dari pembelajaran melukis. Kegiatan membatik dilakukan pada sehelai kain putih dengan menggunakan canting sebagai alat lukisnya untuk bahan melukis pada membatik dipakai cairan malam. Berkaitan dengan tekniknya, kegiatan membatik merupakan bagian dari pembelajaran melukis dengan teknik rintang warna yaitu menutup bagian yang tidak diinginkan terkena warna, kemudian mencelupkan cairan warna yang diinginkan. Teknik membuat batik sebetulnya cukup mengasyikkan dan menantang imajinasi anak melalui proses pembuatan motif, mencanting, dan mewarnai. Saat membuat motif, anak bebas membuat motif, dan saat mewarnai akan merangsang kreativitas seni anak. Saat mencanting, anak akan belajar mengkoordinasikan tangan dan mata dan juga melatih motorik halus anak. Kegiatan mencanting ini dapat melatih konsentrasi, kelenturan, dan kekuatan tangan anak. Kegiatan membatik ini merujuk pada teknik pewarnaan menggunakan bahan malam (wax) yang diaplikasikan ke atas kain menggunakan canting untuk menahan masuknya bahan pewarna (dye).

Kenyataannya memang sedikit sekali lembaga pendidikan yang membuka ekstrakurikuler batik. Padahal kegiatan membatik memiliki banyak hal positif terhadap anak, di masa pertumbuhan dan perkembangannya. Kegiatan membatik anak dapat mempelajari banyak hal, pengenalan budaya Indonesia 
yang menimbulkan rasa seni pada anak. Rasa seni pada anak dapat dikembangkan dengan mengenalkan unsur-unsur seni yang ada dalam kegiatan membatik seperti garis, bentuk, warna, dan tekstur. Begitu juga dengan kemampuan motorik halus anak, rasa percaya diri, dan rasa puas pada anak dapat dikembangkan.

Berdasarkan pemaparan tentang kenyataan dan harapan akan kegiatan membatik oleh anak usia 7-8 tahun, peneliti melakukan penelitian terhadap kegiatan membatik pada anak usia 7-8 tahun di sebuah sanggar seni dan budaya.

\section{KAJIAN TEORITIS}

\section{Kegiatan Membatik pada Anak Usia 7-8 Tahun}

Batik merupakan kegiatan yang menyenangkan karena kegiatan ini memiliki kualitas khusus yaitu rahasia menulis (perubahan warna). Kerajinan masyarakat kontemporer telah mengembangkan kerajinan ini menjadi pribadi ekspresi seni dan diakui secara luas untuk efek yang tidak biasa dan kemungkinan kreatif. Kegiatan membatik dapat digunakan guru untuk memperkenalkan berbagai kegiatan belajar yang berhubungan dengan daerah, seperti belajar dari berbagai budaya dan proses pencetakan kain (Linderman and Marlene, 1984:200).

Kegiatan membatik dapat diberikan kepada anak-anak. Anak selalu ingin belajar melakukan halhal yang baru. Anak belajar dari lingkungan sekitar. Kegiatan bagi anak usia dini dimulai dari lingkungan yang paling dekat dengan anak berlanjut ke arah lingkungan yang lebih jauh. Kegiatan yang memberikan pengalaman yang baru dan bermakna akan bermanfaat bagi perkembangan anak. Membatik pada anak usia 7-8 tahun merupakan kegiatan yang menyenangkan. Kegiatan membatik yang diberikan pada anak adalah kegiatan mencanting (pemberian lilin malam pada pola batik), memberi warna (mencolet dan mencelup), dan pelorodan (menghilangkan lilin dari permukaan kain). Anak akan mencanting dengan alat canting berisi lilin malam ke atas pola yang sudah ada dalam kain. Lilin malam yang digunakan untuk mencanting pola akan menambah pengalaman anak menggunakan canting. Selain itu, kondisi lilin malam yang cair (kental) dan cepat mengering membutuhkan ketelatenan dan kesabaran.

Kegiatan memberi warna atau pewarnaan dapat mengolah perasaan anak. Kegiatan ini dimulai dari proses pemilihan warna ataupun saat memberikan warnanya. Pada saat pewarnaan yaitu ketika kain yang sudah dicanting dicelupkan (pelorodan), anak akan melihat perbedaan ketika warna tersebut semakin lama semakin pekat. Anak akan mempelajari sesuatu yang baru dan melatih memberikan warna.

Penggunaan media membatik pada anak usia dini perlu diperhatikan aspek keamanannya. Aspek keamanan ini adalah keamanan anak dalam menggunakan media membatik. Keamaan yang dipertimbangkan antara lain keamanan dari api yang digunakan untuk meleburkan lilin malam dan keamanan dalam menggunakan canting saat membatik. Untuk itu, yang perlu dipertimbangkan adalah kondisi kompor sewaktu mencanting. Letak kompor ini diletakkan di depan anak dengan jarak yang tidak terlalu dekat dan dengan pengawasan guru. Saat kegiatan mencanting juga perlu dipertimbangkan segi keamanannya. Canting memiliki beberapa komponen, yaitu bagian penampung lilin di saat membatik, bagian corong yang menyalurkan lilin malam ke atas kain, dan bagian pegangan untuk memegang canting. Penggunaan alat canting untuk anak dengan model yang disesuaikan dengan kemudahan memegang canting. Penggunaan alat canting ini dengan memposisikan bagian penampungnya selalu menghadap ke atas sehingga isinya tidak tumpah.

\section{Kegiatan Membatik sebagai Pembelajaran Melukis Pengertian Pembelajaran Melukis}

Pembelajaran melukis adalah cara guru untuk membuat suatu kegiatan membubuhkan warna di atas permukaan datar yang ketebalannya tidak ikut diperhitungkan (karya dua dimensi) untuk menuangkan ide kreatif atau perasaan ke dalam bentuk pewarnaan, dengan menyediakan fasilitas kegiatan tersebut. Anak yang belum memahami bahan ajar dan keterampilan membatik setelah mendapatkan pembelajaran dari guru akan memahami materi bahan ajar serta memiliki keterampilan.

\section{Tujuan Pembelajaran Melukis}

Tujuan utama pembelajaran kegiatan melukis pada anak usia 7-8 tahun adalah agar anak dapat mengintegrasikan antara perasaan, pikiran, dan tindakan dalam kegiatan melukis. Selain itu, sebagai bentuk pengalaman sensori untuk mendapatkan sesuatu yang menyenangkan hingga dapat terwujud kepribadian yang mempunyai arti. Pembelajaran melukis memberikan anak kesempatan untuk meningkatkan dan mengembangkan apa yang dapat atau sudah mereka tahu mengenai bentuk dan unsur dari seni (garis, bentuk, warna, dan tekstur). Selain itu, kegiatan melukis melatih saraf motorik halus anak dan mengembangkan cara untuk menggunakan alat dan teknik yang berhubungan dengan seni.

Pembelajaran melukis juga melatih daya 
konsentrasi dan ketepatan anak dalam melukis suatu objek dan merefleksikannya berdasarkan pengalaman anak yang pernah dialami. Ketepatan anak dapat terlihat dalam menyampaikan suatu arti dari sebuah lukisan yang anak buat. Melalui melukis, anak akan diberi kesempatan untuk mendapatkan kesenangan dari pengalaman sensori yang bervariasi. Kesempatan ini akan melatih daya imajinasi dan kreativitas anak.

\section{Materi Pembelajaran Melukis}

Materi pembelajaran kegiatan melukis adalah membuat gambar ilustrasi berdasarkan ingatan atau pengalaman langsung. Materi melukis ini merupakan komposisi dari unsur-unsur seni rupa yang lain seperti garis, bentuk, warna, dan tekstur (Linderman, 1997:28-29). Berikut penjelasan mengenai lingkup berdasarkan tingkatan sekolah dasar (Rueschhoff, 1969:314): (1) garis, dikatakan sebagai unsur yang paling elementer di bidang seni. Garis adalah hubungan dua buah titik atau jejak titik-titik yang bersambungan atau berderet. Garis dalam melukis mungkin saja tidak ditemukan unsur garis secara aktual, namun bersifat maya atau kesan saja. Misalnya, garis yang ditimbulkan oleh pertemuan dua permukaan atau bidang warna pada lukisan. Pada tingkatan materi melukis ini, anak sudah dapat menggunakan garis dasar. Kemampuan ini digunakan untuk membuat simbol misalkan orang dan rumah; (2) bentuk, pada tingkatan ini, anak akan termotivasi untuk menggunakan bentuk dengan memperkaya simbol; (3) warna, pada tingkatan ini, anak sudah mampu mengenal perbedaan warna yang akan digunakan; dan (4) tekstur, pada tingkatan ini, anak sudah mampu membedakan kualitas tekstur.

\section{Media Pembelajaran Melukis}

Dalam kegiatan melukis, media memiliki dua pengertian. Media dalam pengertian material adalah kertas, kanvas, dan kain, sedangkan media dalam pengertian alat adalah kuas, cat air, pensil, cat poster, dan palet (Kusumawardani, 2004: 11). Namun untuk dapat mengembangkan pembelajaran melukis pada anak mengenai alat, bahan, dan media dapat divariasikan dengan bahan-bahan yang ada di sekitar anak dan sesuai dengan kebutuhan. Berikut beberapa media yang diperlukan dalam kegiatan melukis adalah cat air, kuas, palet, kertas/kanvas, wadah pembersih kuas, dan lap.

\section{Metode Pembelajaran Melukis}

Metode yang dapat digunakan dalam pembelajaran melukis ada beberapa kegiatan: (1) melalui metode demonstrasi. Metode demonstrasi adalah cara penyajian pelajaran dengan memeragakan suatu proses kejadian. Metode demonstrasi biasanya diapli- kasikan dengan menggunakan alat bantu pengajaran seperti gambar, perangkat alat melukis, dan bendabenda lainnya; (2) melalui metode tanya jawab. Metode tanya jawab dapat menarik dan memusatkan perhatian anak. Melalui pertanyaan yang terarah tentang kegiatan melukis, anak akan tertarik dalam mengembangkan imajinasi anak; (3) melalui metode praktik langsung. Metode praktik langsung adalah metode yang memberikan kesempatan kepada anak untuk mempraktikkan secara langsung materi yang diberikan oleh pendidik. Metode ini membantu anak untuk memahami secara langsung materi pembelajaran yang diberikan (Dirdjosoemarto, 2004: 15). Kegiatan ini juga memberikan kesempatan kepada anak untuk mempraktikkan secara langsung materi yang diberikan oleh pendidik. Melalui kegiatan ini, anak juga akan diberi kesempatan untuk dapat bereksplorasi dan bereksperimen. Anak akan mendapat kesempatan untuk menggunakan berbagai media yang akan digunakan dalam pembelajaran melukis.

\section{Kegiatan Pembelajaran Melukis}

Langkah-langkah dalam kegiatan melukis ada tiga tahap yang harus dilalui yaitu, membuat sketsa, pewarnaan, dan mempertegas garis (Ranuhandoko, 2008: 2). Jika tahapan ini dapat dilalui dengan baik dalam pembelajaran, tujuan kegiatan pembelajaran melukis dapat tercapai secara optimal. Tahapan pertama dalam kegiatan melukis, yaitu membuat sketsa dengan menggunakan pensil. Gambar sketsa terdiri dari gambar benda utama atau disebut dengan main object dan latar belakang gambar atau background. Setelah sketsa selesai, mulai mewarnai gambar sebagai langkah kedua. Pewarnaan dapat dimulai dengan mewarnai dari latar belakang gambar. Setelah itu dapat mewarnai benda utama. Melalui proses pewarnaan, biarkan anak bereksperimen sesuai dengan keinginan anak. Langkah yang ketiga adalah mempertegas garis. Setelah proses pewarnaan selesai, dapat mempertegas garis dengan mengikuti setiap garis dalam lukisan tersebut dengan warna yang lebih gelap. Hal ini dilakukan untuk mempertegas batas benda-benda yang satu dengan yang lain.

\section{Evaluasi Pembelajaran Melukis}

Kaitannya dalam hal melukis, evaluasi dilakukan secara visual atau observasi dengan menggunakan sejenis format penilaian yang terdiri atas penilaian dari segi komposisi garis, bentuk, warna, dan tekstur. Untuk mengetahui perkembangan anak, guru harus membuat batas-batas kegiatan untuk mengidentifikasi setiap perkembangan anak dengan mengobservasi setiap anak dengan membuat tujuan pendekatan untuk pertumbuhan dan perkembangan keahlian anak 
(Dogde dan Colker, 2000: 180). Setelah itu, dapat dilakukan kegiatan displaying (memajang hasil karya anak). Kegiatan ini dilakukan agar anak merasa dihargai hasil karyanya.

\section{Karakteristik Anak Usia 7-8 Tahun Perkembangan Fisik}

Dalam pertumbuhan anak usia 7-8 tahun, terlihat kemampuan visual anak sudah lebih terkoordinasi dengan baik, sehingga anak mulai siap untuk membaca petunjuk atau mengerjakan tugas yang membu-tuhkan koordinasi mata dan tangan (Sue dan Carol, 2002: 146). Karakteristik perkembangan fisik anak usia SD (7-8 tahun) mulai beranjak matang, maka perkembangan motorik anak sudah dapat terkoordinasi dengan baik. Setiap gerakannya sudah selaras dengan kebutuhannya. Selain itu, pada masa ini juga ditandai dengan kelebihan gerak atau aktivitas motorik yang lincah. Oleh karena itu, usia ini merupakan masa yang ideal untuk belajar keterampilan yang berkaitan de-ngan motorik, seperti menulis, menggambar, melukis, dan berenang.

Perkembangan Kognitif

Pada usia sekolah dasar (7-8 tahun), anak sudah dapat mereaksi rangsangan intelektual, atau melaksanakan tugas-tugas belajar yang menuntut kemampuan intelektual atau kemampuan kognitif, seperti membaca, menulis, dan menghitung. Sebelum masa ini, yaitu masa prasekolah, daya pikir anak masih bersifat imajinatif, berangan-angan, sedangkan pada usia 7-8 tahun daya pikirnya sudah berkembang ke arah berpikir konkret dan rasional (dapat diterima akal). Hal ini sesuai dengan pernyataan Piaget yang menyatakan bahwa "anak usia 7-11 tahun berada pada tahap konkret, yang dicirikan dengan perkembangan sistem pemikiran yang didasarkan pada aturan-aturan tertentu yang logis" (Suparno, 2001: 69). Berdasarkan hal tersebut, dapat dipahami bahwa anak usia 7-8 tahun kemampuan berpikirnya masih dalam bentuk konkret sehingga dalam menyampaikan materi pada anak usia tersebut harus dalam bentuk yang nyata.

\section{Perkembangan Sosio-emosional}

Karakteristik perkembangan sosio-emosional anak usia 7-8 tahun ditandai dengan keinginan membuat kelompok; mulai bersosialisasi lebih luas lagi; belajar tentang konsep diri melalui orang lain seperti teman kelompok dan orangtua, menunjukkan rasa malu; berjuang dengan perasaannya ketika perasaan rendah dirinya muncul dan rasa percaya dirinya lebih berkembang (Miles dan William, 2004: 109). Mengingat hal tersebut, maka pendidik diharapkan mempunyai kepedulian untuk menciptakan situasi belajar yang menyenangkan dan kondusif bagi terciptanya proses belajar-mengajar yang efektif, sehingga perkembangan sosio-emosional anak dapat berkembang secara optimal.

\section{METODOLOGI PENELITIAN}

Pendekatan yang digunakan dalam penelitian ini adalah pendekatan deskriptif kualitatif karena disesuaikan dengan tujuan yang ingin dicapai. Penelitian deskriptif adalah penelitian yang bertujuan untuk mendeskripsikan apa-apa yang saat ini berlaku, yang di dalamnya terdapat upaya mendeskripsikan, mencatat, menganalisis, dan menginterpretasikan kondisi-kondisi yang sekarang terjadi (Mardalis, 2004: 26). Penelitian ini tidak dimaksudkan untuk menguji hipotesis tertentu, tetapi hanya untuk mengumpulkan informasi mengenai status suatu gejala yang ada, yaitu keadaan gejala menurut apa adanya pada saat penelitian dilakukan tanpa harus merumuskan hipotesis.

Penelitian ini mengambil lokasi di Sanggar Seni dan Budaya Jawa Jawi Java, Jakarta Selatan. Penentuan lokasi diambil sesuai dengan pendapat Spradley (1999:52), yaitu sederhana, mudah melakukannya, tidak begitu kentara saat melakukan penelitian, mudah mendapatkan izin, serta kegiatan dapat terjadi berulang-ulang. Berdasarkan pertimbangan tersebut, dipilihlah Sanggar Seni dan Budaya Jawa Jawi Java, Jakarta Selatan. Alasan lain dipilihnya sanggar tersebut karena Sanggar Seni dan Budaya Jawa Jawi Java mengadakan kegiatan membatik secara rutin.

Penelitian ini dilaksanakan pada bulan Juni 2009 dengan informan penelitian adalah guru sanggar dan pemilik sanggar. Untuk mendapatkan data yang terkait dengan variabel penelitian, teknik pengumpulan data yang digunakan antara lain teknik observasi, teknik wawancara, dan teknik dokumentasi. Dalam menganalisis data, peneliti menggunakan analisis nonstatistik atau data dianalisis sesuai dengan penggunaan hasil dari jawaban informasi pertanyaan yang diajukan dan yang tidak berkaitan dengan skor ataupun skala, tetapi dideskripsikan dalam suatu penjelasan dalam bentuk narasi atau kalimat. Teknik analisis data yang digunakan adalah empat tahapan metode komparatif (Glaser dan Strauss) seperti yang dikutip oleh Moleong (2007: 272-277), yaitu "(1) perbandingan kejadian-kejadian yang aplikatif terhadap setiap kategori, (2) integrasi katagori dan kawasannya, (3) pembatasan teori, dan (4) penulisan teori". Selanjutnya, untuk memperoleh data yang absah perlu diupayakan pengecekan keabsahan data dengan menggunakan: (1) perpanjangan pengamatan, (2) 
peningkatan ketekunan, (3) triangulasi, dan (4) member check.

\section{HASIL PENELITIAN}

\section{Deskripsi Umum}

Hasil observasi, wawancara, dan dokumentasi menunjukkan bahwa Sanggar Seni dan Budaya Jawa Jawi Java melakukan kegiatan membatik pada anak usia 7-8 tahun. Kegiatan ini bertujuan untuk menjaga kelanggengan budaya Jawa dengan melestarikan dan mempraktikkan nilai-nilai di dalamnya dalam kehidupan sehari-hari. Hal inilah yang mendorong pencinta budaya Jawa menghadirkan seni dan budaya Jawa di Jakarta melalui Sanggar Jawa Jawi Java. Melalui wahana ini, diharapkan dapat secara bersamasama menjaga kelanggengan budaya Jawa serta mempelajari, mengapresiasi, serta memupuk minat bersama terhadap seni dan budaya Jawa, khususnya budaya Jawa Tengah, Solo, dan Yogyakar-ta. Pada akhirnya, kegiatan ini diharapkan dapat seca-ra bersama-sama berjuang dalam nguri-uri kabudayan Jawi di tengah era modernisasi ini.

\section{Deskripsi Khusus}

Berdasarkan hasil interpretasi data yang telah diperoleh, didapat hasil penelitian sebagai berikut.

\section{Tujuan Kegiatan Membatik.}

Tujuan kegiatan membatik di Sanggar Seni dan Budaya Jawa Jawi Java sudah nyata yaitu kegiatan membatik memberikan kesempatan kepada anak untuk meningkatkan dan mengembangkan apa yang dapat atau sudah mereka tahu mengenai bentuk dan unsur dari seni (garis, bentuk, warna dan tekstur). Anak diberikan kebebasan untuk mengembangkan bentukbentuk dan unsur-unsur seni tersebut. Selain itu, juga untuk mengembangkan keterampilan yang berkaitan dengan motorik halus anak.

\section{Materi Kegiatan Membatik.}

Materi yang diberikan guru di Sanggar Seni dan Budaya Jawa Jawi Java sudah sesuai, yaitu cara membuat motif, mencanting motif, dan mewarnai kain. Kegiatan ini meliputi penggunaan unsur-unsur seni rupa, yaitu garis, bentuk, warna, dan tekstur. Saat anak membuat pola, terlihat penggunaan garisnya, dan juga saat mencanting anak akan berusaha untuk membuat garis sesuai dengan pola yang digambarnya. Bentukbentuk gambar dalam membatik bebas. Hal ini yang membuat anak boleh mengekspresikan bentuk sesuai dengan keinginannya. Kebebasan diberikan agar anak dapat membuat bentuk sesuai keinginannya yang terlihat saat anak membuat pola dan mencanting. Di samping itu juga terlihat, anak bebas membuat bentukbentuk, misalnya isen-isen.

Tahap pencelupan diawali dengan penjelasan guru tentang warna yang digunakan dalam pencelupan. Anak boleh memilih warna namun guru juga memberikan penjelasan bahwa tidak semua warna dapat digunakan saat pencelupan dalam kegiatan membatik. Pada saat mencolet, guru membebaskan anak untuk memilih dan mengekspresikan warna yang digunakan. Saat memberikan kain batik, anak selalu bertanya dan mengetahui dengan sendirinya tekstur kain yang diberikan.

3. Metode Kegiatan Membatik.

Metode yang digunakan pada kegiatan membatik di Sanggar Seni dan Budaya Jawa Jawi Java adalah metode demonstrasi dan metode praktik langsung. Metode demonstrasi dan metode praktik langsung membantu anak untuk memahami secara langsung materi pembelajaran yang diberikan. Metode ini juga memberikan kesempatan kepada anak untuk melihat dan mempraktikkan secara langsung materi yang diberikan oleh guru. Melalui metode ini, anak akan diberi kesempatan untuk bereksplorasi dan bereksperimen sehingga anak dapat memahami secara langsung materi yang diberikan. Sebaiknya, metode yang digunakan lebih beragam, seperti metode tanya jawab. Dengan adanya metode tanya jawab ini guru akan mengetahui pemahaman anak.

\section{Media Kegiatan Membatik.}

Media yang digunakan pada kegiatan membatik di Sanggar Seni dan Budaya Jawa Jawi Java belum terlihat. Media dalam kegiatan membatik ini langsung praktik. Seharusnya, media disediakan untuk membantu guru menyampaikan materi yang ingin disampaikan karena mengingat media mempunyai peranan yang sangat penting dalam membantu/memahami materi yang akan disampaikan. Hal yang perlu diperhatikan dalam pemilihan media ialah menyesuaikan media dengan materi yang akan disampaikan. Dengan menggunakan alat bantu, pelajaran akan lebih menarik, mudah dipahami, hemat waktu, tenaga, dan hasil belajar akan lebih bermakna.

Persiapan media media kelihatannya sudah dilakukan dengan baik. Hal ini dapat terlihat ketika sebelum kegiatan membatik dimulai, guru sudah mempersiapkan media yang akan digunakan. Persiapan seperti ini, akan dilakukan untuk memperlancar jalannya kegiatan pembelajaran.

5. Proses Kegiatan Membatik.

Dalam kegiatan membatik di sanggar ini, yaitu kegiatan pewarnaan dengan teknik celup dan pelorodan, anak hanya sebagai pengamat. Adapun guru 
dibantu dengan pegawai melakukan kegiatan mencelup dan pelorodan. Alasan yang menjadikan dasar tidak diperbolehkan anak untuk melakukan kegiatan ini karena saat tahap mencelup, bahan cat warna kain yang digunakan mengandung bahan kimia, yang berbahaya bagi kulit anak yang pada usia 7-8 tahun memiliki tingkat sensitivitas yang tinggi sehingga dikhawatirkan dapat menimbulkan rasa gatal. Begitu juga saat teknik pelorodan. Teknik merebus kain di atas kompor ini untuk anak usia 7-8 tahun belum dapat dilakukan. Anak hanya mengikuti kegiatan ini dengan mengamati secara langsung proses pencelupan dan pelorodan.

Dari kegiatan membatik yang diberikan tersebut, kegiatan yang paling penting diberikan kepada anakanak adalah pada proses membatik dan memberi warna. Pada kegiatan membatik, anak diajak untuk menggambar bentuk (motif) sesuai dengan kreasi dan ide anak ke dalam media. Setelah membuat motif, anak akan mencanting lilin malam. Sifat dari bahan lilin malam akan memengaruhi perbedaan anak saat melukis. Di sini, lilin malam tersebut seperti menggantikan tinta dalam bolpoin atau grafit di dalam pensil. Kondisi lilin malam yang cair (kental) dan cepat mengering membutuhkan ketelatenan yang berbeda saat melukis di atas kertas.

Kegiatan memberi warna atau pewarnaan dapat mengolah perasaan anak, dari proses pemilihan warna sampai saat memberikan warna. Pada pencelupan warna, anak akan melihat perbedaan ketika warna tersebut semakin lama semakin pekat. Di sini, anak akan mempelajari sesuatu yang baru untuk memberikan warna. Untuk proses pewarnaan colet atau warna dengan kuas, anak dibebaskan dalam pemilihan warna sehingga anak dapat berkreasi menggunakan warna yang sesuai dengan keinginan anak.

6. Evaluasi Kegiatan Membatik.

Kegiatan evaluasi dilakukan oleh guru di sanggar seni dan budaya Jawa Jawi Java setelah setiap kegiatan selesai. Namun, dalam pelaksanaan evaluasi yang dilakukan guru tidak dicatat dalam buku atau lembar evaluasi dan juga tidak terdapatnya nilai atau indikator yang dijadikan acuan dalam melakukan evaluasi. Hal ini membuat perkembangan anak dalam kegiatan membatik kurang terlihat jelas. Evaluasi ini bukan hanya untuk melihat bagaimana hasil akhir dari karya anak tetapi juga untuk melihat apakah kegiatan membatik sudah sesuai dengan yang direncanakan atau belum.

\section{PENUTUP}

\section{Kesimpulan}

Dari hasil penelitian tentang kegiatan membatik pada anak usia 7-8 tahun di Sanggar Seni dan Budaya Jawa Jawi Java, dapat disimpulkan bahwa kegiatan membatik pada anak usia 7-8 memberikan kesempatan kepada anak untuk meningkatkan dan mengembangkan apa yang dapat atau sudah mereka tahu mengenai bentuk dan unsur dari seni (garis, bentuk, warna dan tekstur). Selain itu, kegiatan membatik juga akan mengenalkan anak tentang unsur-unsur seni yang dapat dikembangkan sesuai dengan karakteristik anak usia 7-8 tahun dan juga untuk melestarikan dan menjaga kelanggengan hasil budaya bangsa. Pengenalan dan pengembangan tentang unsur-unsur seni ini akan terlihat dalam tujuan membatik, materi membatik, metode membatik, media membatik, proses kegiatan membatik, dan evaluasi membatik.

\section{Saran}

Beberapa hal yang perlu diperhatikan pada kegiatan membatik pada anak usia 7-8 tahun adalah guru sebaiknya lebih memperhatikan tujuan kegiatan membatik secara keseluruhan, yaitu lebih dispesifikasikan agar lebih terlihat berkesinambungan. Metode yang digunakan pun sebaiknya disesuaikan dengan keadaan anak dan diusahakan lebih beragam. Pada saat kegiatan membatik, guru sebaiknya mengondisikan anak dengan baik dan setiap kegiatan sebaiknya diberlakukan peraturan mengenai hal-hal yang perlu dilakukan dan yang tidak boleh dilakukan. Penyediaan media pun sebaiknya dilakukan dengan baik. Selain itu, dalam mengevaluasi kegiatan membatik, sebaiknya guru juga mencatat dalam buku atau lembar evaluasi nilai atau indikator yang dijadikan acuan dalam melakukan evaluasi sehingga perkembangan anak dalam kegiatan membatik dapat terlihat jelas.

\section{DAFTAR PUSTAKA}

Browne, K.W. \& Gardon, A.M. (2004). Beginnings and beyond: Foundations in early childhood education. 6th ed. USA: Thomas Delmar Learning.

Carol \& Brekamp, S. (2002). Developmentally appropriate practice in early childhood program. Washington, D.C: National Association for the Education of Young Children.

Colker, L.J. \& Dogde, D.T. (2000). The creative curriculum for early childhood: Teaching strategy. Washington DC. 
Dirdjosoemarto, dkk. (2004). Strategi belajar mengajar. Bandung: FPMIPA UPI dan JICA IMSTEP.

Hartono. (2005). Konstruktivisme sebuah alternatif pembelajaran seni anak usia dini. Semarang: Harmonia Jurnal Pengetahuan dan Pemikiran Seni.

James, P.S. (1999). Participant observation. New York: McGraw-Hill Book Company.

Kusumawardani, D. (2004). Seni, seniman/wati dan kreativitas. Jakarta: FBS UNJ.

Linderman, E.W. \& Linderman, M.M. (1984). Arts $\mathcal{E}$ crafts for the classroom. New York: Macmillan Publishing.

Linderman, M.G. (1997). Art in the elementary school. Brown \& Benchmark: Madison, WI.

Mardalis. (2004). Metode penelitian suatu pendekatan proposal. Jakarta: Bumi Aksara.

Moleong, L.J. (2007). Metode penelitian kualitatif. Bandung: Remaja Rosdakarya.

Suparno, P. (2001). Teori perkembangan kognitif Jean Piaget. Yogyakarta: Kanisius.

Ranuhandoko, N. (2008). Teknik dasar mewarnai dengan cat air. Jakarta: Wahyumedia.

Rueschhoff, P. (1969). Teaching art in the elementary school. New York: Ronal Press Company.

\section{KETERANGAN PENULIS}

Lina Indra Kartika, lahir pada tanggal 1 Januari 1987, lulusan S1G PAUD FIP UNJ tahun 2009.

Pembimbing 1: Dra. Sri Wulan, M. Si, Pembimbing 1 (materi), dosen pada program studi PG PAUD FIP UNJ. Pembimbing 2: Sri Indah Pujiastuti, M. Pd, Pembimbing 2 (metodologi), dosen pada program studi PG PAUD FIP UNJ. 